\title{
Pengaruh Budaya \& Bargaining Power Terhadap Partisipasi Kerja dan Sekolah Anak di Jawa Timur
}

\author{
Faishol Amir \\ Khusnul Ashar \\ Devanto Shasta Pratomo
}

Fakultas Ekonomi dan Bisnis, Universitas Brawijaya

\begin{abstract}
ABSTRAK
Makalah ini meneliti pengaruh budaya dan Bargaining power terhadap partisipasi sekolah dan kerja anak di Jawa Timur. Prevalensi anak usia 10-17 tahun yang bekerja di Jawa Timur sekitar 4,74\%. Sekitar 28,03\% anak yang bekerja masih bersekolah. Sedangkan anak putus sekolah mencapai 11,28\%. Mengacu pada teori Collective Model dan menggunakan metode analisis regresi multinomial logit pada data Survei Penduduk Antar Sensus (SUPAS) 2015, makalah ini menyimpulkan bahwa budaya yang diproxikan melalui tlatah (kawasan kebudayaan) berpengaruh signifikan terhadap partisipasi sekolah dan kerja anak. Anak yang berasal dari tlatah Arek paling berpeluang untuk bekerja. Anak yang berasal dari tlatah Pandalungan paling kecil peluangnya untuk sekolah. Sedangkan anak dari tlatah Madura Pulau paling berpeluang untuk sekolah sambil bekerja. Menariknya, saat pendidikan ibu setara bahkan lebih tinggi dari pendidikan ayah, peluang anak bekerja semakin besar dan sebaliknya peluang anak untuk sekolah semakin kecil.
\end{abstract}

Kata kunci: multinomial logit, collective model, partisipasi kerja dan sekolah anak Klasifikasi JEL: C35, D7, J13

\section{Culture \& Bargaining Power Influence on School and Working Participation of Child in East Java}

\begin{abstract}
This paper examines the influence of cultural and bargaining Power on child labor and school participation in East Java. The prevalence of children aged 10-17 years who work in East Java is around 4.74\%. About 28.03\% of children who work are still in school. Whereas school dropouts reach $11.28 \%$. Referring to the theory of collective model and using the method of multinomial logit regression analysis on the Intercensal Population Survey (SUPAS) data in 2015, this paper concludes that culture proxied through tlatah had a significant effect. Children who come from Arek tlatah are most likely to work. Children from the Pandalungan tlatah are the least likely to go to school. While children from Madura Pulau tlatah are most likely to go to school while working.. Interestingly, if maternal education is equal or even higher than that of fathers, children's participation in work increases and conversely the participation of school children actually decreases.
\end{abstract}

Keywords: multinomial logit, collective model regression, child labor and school participation JEL classification: $C 35, D 7, J 13$

\section{PENDAHULUAN}

Menurut nilai dan produk khas budaya yang dimiliki, Sutarto (2004) membagi Jawa Timur ke dalam sepuluh kawasan kebudayaan (Tlatah). Empat tlatah besar diantaranya meliputi: tlatah Arek, Mataraman, Madura Pulau, dan Pandalungan. Masing-masing tlatah memiliki keragaman corak dan ciri khas perilaku masyarakatnya, termasuk dalam hal partisipasi sekolah dan kerja anak.

Jawa Timur merupakan provinsi berpenduduk terbanyak ke - 2 di Indonesia dengan jumlah penduduk sebanyak 39,29 juta jiwa pada tahun 2017. Sekitar 22,63\% diantaranya adalah penduduk usia muda (0-14 tahun). Dengan potensi SDM yang melimpah, ada satu permasalahan yang cukup besar, yaitu jumlah anak yang bekerja 
cukup tinggi. Dari data BPS (2017), sekitar 4,67\% dari total anak berusia 10-17 tahun di Jawa Timur adalah anak yang bekerja pada tahun 2016 .

Dalam teori keputusan rumah tangga, anak bekerja atau tidak bekerja serta sekolah atau tidak sekolah tergantung pada keputusan rumah tangga. Pendekatan dalam teori keputusan rumah tangga terbaru yaitu Collective Model mengasumsikan suami dan istri bisa memiliki preferensi dan bargaining power yang berbeda terhadap kesejahteraan anak mereka. Apakah akan melibatkan anak bekerja atau tidak serta bersekolah atau tidak.

Cukup banyak studi empiris tentang pengaruh budaya yang diproxikan melalui etnis dan bahasa terhadap partisipasi kerja dan sekolah anak. McEwan \& Trowbridge (2007), Vasquez \& Bohara (2010), serta Contreras et al. (2007) menunjukkan bahwa etnis penduduk asli (indigenous) lebih memungkinkan menjadi pekerja anak dan kurang memungkinkan untuk sekolah dari pada penduduk nonindigenous. Sedangkan kemampuan menguasai bahasa nasional sebagai sarana komunikasi berpengaruh signifikan terhadap prestasi anak di sekolah, tingkat putus sekolah dan pendapatan anak jika bekerja (Patrinos \& Psacharopoulos; 1995).

Sejauh pengetahuan penulis, belum ada penelitian-penelitian sebelumnya tentang pengaruh budaya terhadap partisipasi kerja dan sekolah anak yang di Jawa Timur yang mengacu pada konsep Collective Model. Maka penelitian ini dilakukan untuk mengetahui pengaruh sosial, ekonomi dan budaya terhadap partisipasi kerja dan sekolah anak di Jawa Timur dengan menggunakan data SUPAS 2015.

\section{Teori Collective Model Tentang Partisipasi Kerja dan Sekolah Anak}

Penjelasan secara teoritis tentang partisipasi kerja dan sekolah anak dikembangkan dari konsep Ahmed \& Ray (2011) serta Basu \& Ray (2002) yang menganut konsep Collective Model. Di mana orang tua bisa memiliki preferensi yang berbeda terkait dengan sekolah anak-anak mereka.

Pertimbangkan rumah tangga yang terdiri dari ayah $(j=f)$ dan ibu $(j=m)$ dan sejumlah $\mathrm{K}$ anak-anak pada titik waktu tertentu. Fertilitas diasumsikan eksogen. Setiap orang tua peduli tentang konsumsinya sendiri dan kualitas (pencapaian) pendidikan anak-anak mereka. Semua keputusan yang dibuat oleh orang tua bersifat altruistik, dan anak-anak diperlakukan sebagai penerima.

Asumsikan setiap orang tua memiliki fungsi utilitas yang berbeda dan rumah tangga memaksimalkan rata-rata bobot dari dua fungsi ini $\theta \in[0,1]$ dengan bobot yang menunjukkan keseimbangan kekuatan pasangan orang tua di dalam rumah tangga.

$$
\begin{aligned}
\max U_{j}= & \left\{\theta\left[U_{m}\left(C_{m}, C_{b}, S, Z\right)\right]+\right. \\
& \left.(1-\theta)\left[U_{f}\left(C_{f}, C_{b}, S, Z\right)\right]\right\} \\
\operatorname{dengan} j= & m, f .
\end{aligned}
$$

Di mana $C_{j}$ adalah total barang konsumsi pribadi masing-masing orang tua, $C_{b}$ adalah barang konsumsi bersama seluruh anggota rumah tangga (selain biaya sekolah anak dan $C_{j}$ ), $\mathrm{S}$ adalah pencapaian pendidikan anak-anak, dan $\mathrm{Z}$ merupakan vektor karakteristik individu dan rumah tangga serta bersifat eksogen. Sedangkan $\theta$ merupakan fungsi yang tergantung pada variabel lain yang terkandung di dalam $\mathrm{Z}$ dan juga bersifat eksogen. Berbeda dengan konsep dari Ahmed \& Ray (2011) yang hanya memperhatikan pada barang konsumsi individu masing-masing kedua orang tua. Pada penelitian ini, barang konsumsi dibedakan antara barang konsumsi pribadi orang tua dengan barang konsumsi bersama seluruh anggota rumah tangga (selain biaya sekolah anak).

Orang tua mengalokasikan jumlah total waktu anak (T) antara waktu sekolah anak (S) dan waktu bekerja (L). Oleh karena itu, maksimalisasi fungsi utilitas di atas tunduk pada batasan waktu berikut:

$\mathrm{T}=\mathrm{S}+\mathrm{L}$

Pertimbangkan pendapatan rumah tangga, $Y$ adalah fungsi dari pendapatan non-kerja (disimbolkan $A_{i}$ ) dari orang tua dan pendapatan kerja orang tua (disimbolkan $w_{j} L_{w_{j}}$ ). Karena pendapatan rumah tangga $Y$ dan pendapatan anak jika bekerja $w L_{w}$ harus mencukupi kebutuhan rumah tangga dan biaya sekolah anak. Maka batas anggaran bisa dituliskan sebagai berikut:

$$
C_{t}=Y\left(Z, A_{j}, w_{j} L_{w_{i}}\right)-p_{s} S+w L_{w}
$$

Dimana $C_{j}+C_{b}$ adalah harga barang konsumsi gabungan, yaitu yang dinormalisasikan menjadi 1 dan menunjukkan biaya sekolah. Oleh karena itu, masalah optimalisasi orang tua bisa ditulis sebagai berikut:

$$
\begin{aligned}
\max U_{j}= & \left\{\theta\left[U_{m}\left(C_{m}, C_{b}, S, Z\right)\right]+\right. \\
& \left.(1-\theta)\left[U_{f}\left(C_{f}, C_{b}, S, Z\right)\right]\right\}
\end{aligned}
$$


Yang tunduk pada batasan:

$C_{t}=Y\left(Z, A_{j}, w_{j} L_{w_{j}}\right)-p_{s} S+w L_{w}$ dan $\mathrm{T}=\mathrm{S}+\mathrm{L}$

Dimana menurut Basu \& Ray (2002), solusi dalam menyelesaikan persamaan batasan di atas dengan membentuk persamaan berikut:

$$
C_{t}^{*}=C_{t}\left(\theta, A_{j}, w_{j} L w_{j}, w L_{w}\right)
$$

Masalah maksimalisasi terbatas tersebut menghasilkan suatu sistem persamaan permintaan untuk anak bersekolah, yaitu:

\section{$S_{i}^{*}=f\left(Z, L_{i}, \Omega_{j}, \theta_{j}\right), \quad i=1, \ldots, K \quad$ (5)}

Dimana $\Omega$ menunjukkan pendapatan total rumah tangga.

Menurut Basu \& Ray (2002), Li adalah fungsi dari, yaitu:

\section{$L_{i}=f\left(\Omega_{j}, \theta_{j}\right), \quad i=1, \ldots \ldots \ldots$}

Sehingga untuk menghilangkan pengaruh endogenitas dari $\mathrm{L}_{\mathrm{i}}$ pada persamaan (5), persamaan $S_{i}^{*}$ menjadi:

$$
S_{i}^{*}=f\left(Z, \Omega_{j}, \theta_{j}\right), \quad i=1, \ldots, K \quad \text { (6) }
$$

Maka persamaan penawaran tenaga kerja anak bisa dinyatakan sebagai:

$$
L_{i}=f\left(Z, \Omega_{j}, \theta_{j}\right), \quad i=1, \ldots \ldots \ldots K \quad(7)
$$

Sehingga dari persamaan (6) dan (7), persamaan untuk anak bekerja dan sekolah bisa dinyatakan sebagai fungsi dari:

$$
S L_{i}=f\left(Z, \Omega_{j}, \theta_{j}\right), \quad i=1, \ldots \ldots \ldots K \quad \text { (8) }
$$

Dimana $S L_{i}$ adalah fungsi dari anak bersekolah atau bekerja yang dipengaruhi oleh karakteristik anak dan rumah tangga (sosial), pendapatan rumah tangga (ekonomi), serta perbedaan bargaining power kedua orang tua.

Dengan mengacu pada beberapa bukti empiris tentang pengaruh budaya terhadap partisipasi sekolah dan kerja anak, maka persamaan
(8) di atas dapat ditulis menjadi.

$$
S L_{i}=f\left(Z, \Omega_{j}, \theta_{j}, \sigma\right), \quad i=1, \ldots \ldots \ldots . K \quad \text { (9) }
$$

Dimana $\sigma$ adalah faktor budaya yang diproxikan dari tlatah anak dan bahasa.

\section{METODE PENELITIAN}

Analisis pengaruh budaya dan bargaining power terhadap partisipasi sekolah dan kerja anak dilakukan dengan estimasi regresi multinomial logit. Penelitian ini menggunakan data sekunder cross section yang berasal dari data Survei Penduduk Antar Sensus (SUPAS2015) tahun 2015 di Jawa Timur oleh BPS.

Variabel dependennya adalah status sekolah dan kerja anak yang dibedakan atas empat kategori, yaitu $0=$ anak yang bekerja dan sedang sekolah, $1=$ anak bekerja dan tidak sekolah, $2=$ anak tidak bekerja dan sedang sekolah, dan $3=a n a k$ tidak bekerja dan tidak sekolah. Status anak bekerja serta sekolah atau tidak, didasarkan pada kegiatan bekerja seminggu terakhir interval waktu pengamatan.

Sedangkan variabel independennya meliputi beberapa karakteristik anak \& rumah tangga serta budaya.

\section{HASIL DAN PEMBAHASAN \\ Deskripsi Data}

Jumlah observasi dalam penelitian ini sebanyak 34.928 responden anak usia 10-17 tahun di Jawa Timur. Ditinjau dari karakteristik anak, ada 17.970 anak laki-laki dan 16.958 anak perempuan.

\begin{tabular}{|c|c|c|c|c|c|c|c|}
\hline \multirow{2}{*}{\multicolumn{2}{|c|}{$\begin{array}{c}\text { Status anak bekerja dan } \\
\text { Sekolah }\end{array}$}} & \multicolumn{6}{|c|}{ Tlatah anak } \\
\hline & & Madura pulau & Arek & Mataraman & Pandalungan & Lainnya & Total \\
\hline \multirow[b]{2}{*}{ Bekerja dan Sekolah } & $\Sigma$ & 122 & 88 & 163 & 62 & 29 & 464 \\
\hline & $\%$ & 26,29 & 18,97 & 35,13 & 13,36 & 6,25 & 100 \\
\hline \multirow{2}{*}{$\begin{array}{l}\text { Bekerja dan Tidak } \\
\text { Sekolah }\end{array}$} & $\Sigma$ & 209 & 273 & 374 & 269 & 66 & 1.191 \\
\hline & $\%$ & 17,55 & 22,92 & 31,4 & 22,59 & 5,54 & 100 \\
\hline \multirow{2}{*}{$\begin{array}{l}\text { Tidak Bekerja } \\
\text { namun Sekolah }\end{array}$} & $\Sigma$ & 3,551 & 8,55 & 10,561 & 6,1 & 1,763 & 30.525 \\
\hline & $\%$ & 11,63 & 28,01 & 34,6 & 19,98 & 5,78 & 100 \\
\hline \multirow{2}{*}{$\begin{array}{l}\text { Tidak Bekerja dan } \\
\text { Tidak Sekolah }\end{array}$} & $\Sigma$ & 383 & 662 & 846 & 743 & 114 & 2.748 \\
\hline & $\%$ & 13,94 & 24,09 & 30,79 & 27,04 & 4,15 & 100 \\
\hline \multirow{2}{*}{ Total } & $\Sigma$ & 4,265 & 9,573 & 11,944 & 7,174 & 1,972 & 34.928 \\
\hline & $\%$ & 12,21 & 27,41 & 34,2 & 20,54 & 5,65 & 100 \\
\hline
\end{tabular}

Prevalensi anak yang bekerja sebanyak $4,74 \%$. Sedangkan anak yang putus sekolah mencapai 11,28\%. Secara lengkap, deskripsi

Tabel 1: Status Kerja dan Sekolah Anak berdasarkan Usia Anak di Jawa Timur, SUPAS 2015

Sumber: Hasil Olah Data Supas 2015 Jawa Timur 
status anak bekerja dan sekolah ditampilkan pada tabel 1.10-17 tahun di Jawa Timur. Ditinjau dari karakteristik anak, ada 17.970 anak laki-laki dan 16.958 anak peREMpuan. Prevalensi anak yang bekerja sebanyak $4,74 \%$. Sedangkan anak yang putus sekolah mencapai $11,28 \%$. Secara lengkap, deskripsi status anak bekerja dan sekolah ditampilkan pada tabel 1.

Ditinjau dari tingkat pendidikan terakhir, ada $38,24 \%$ anak tidak lulus SD; 60,49\% anak lulus pendidikan dasar; dan 1,27\% lulus pendidikan menengah.

Prevalensi anak yang hidup di wilayah pedesaan mencapai $51,92 \%$ dan yang hidup di wilayah perkotaan mencapai 48,08\%. Dari keseluruhan sampel, ada 34,20\% anak tinggal di kawasan tlatah Mataraman; 27,41\% di wilayah tlatah Arek; $12,21 \%$ di kawasan tlatah Madura Pulau; 20,54\% di wilayah tlatah Pandalungan; dan sisanya 5,65\% di wilayah tlatah lainnya. Ditinjau dari kemampuan berbahasa Indonesia, masih ada $1,75 \%$ anak yang tidak mampu berbahasa Indonesia dengan baik dan benar.

\section{Hasil Estimasi dengan Marginal Effects}

\section{a. Pengaruh Tlatah Anak}

Empat kelompok tlatah terbesar di Jawa Timur meliputi: Tlatah Madura Pulau, tlatah Arek, tlatah Mataraman, Tlatah Pandalungan. Sebagai acuan dalam penelitian ini, dipilih tlatah Madura Pulau karena proporsi anak bekerja terhadap jumlah anak usia 10-17 tahun paling besar di antara tlatah lain.

Dari nilai marginal effects pada keempat kategori aktivitas sekolah dan bekerja anak, dapat disimpulkan bahwa anak yang berasal dari tlatah Arek paling berpeluang bekerja $(\mathrm{ME}=0,011)$ dibandingkan anak dari tlatah lainya. Sedangkan

Tabel 2: Hasil perhitungan Multinomial Logit dengan Marginal effects pada Status Sekolah dan Kerja Anak

\begin{tabular}{|c|c|c|c|c|c|c|c|c|}
\hline \multirow{3}{*}{ variabd ind ependen } & \multicolumn{8}{|c|}{ Status sekolah dan kerja anak (variabel dependen) } \\
\hline & \multicolumn{2}{|c|}{ Bekerja } & \multicolumn{2}{|c|}{ Sekolah } & \multicolumn{2}{|c|}{ Bekerja dan sekolah } & \multicolumn{2}{|c|}{ Tidak bekerjadan tidak } \\
\hline & M.E & P.Value & M.E & P.Value & M.E & P.Value & M.E & P.Value \\
\hline \multicolumn{9}{|l|}{ Tlatah } \\
\hline Arek & 0,011 & $0,002 * * *$ & $-0,019$ & $0,004 * *$ & $-0,010$ & $0,000 * * *$ & 0,017 & $0,001 * * *$ \\
\hline Mataraman & $-0,001$ & 0,810 & 0,005 & 0,396 & $-0,007$ & $0, \infty 03 * * *$ & 0,004 & $0,40 B$ \\
\hline Pandalungan & 0,003 & 0,342 & $-0,022$ & $0,000^{* * *}$ & $-0,013$ & $0,000 * * *$ & 0,031 & $0,000^{* * *}$ \\
\hline Tlatah lain & 0,001 & 0,773 & 0,016 & $0,039 *$ & $-0,007$ & $0,069^{*}$ & $-0,011$ & $0,079^{*}$ \\
\hline Kemampuan BHS.Indon esia & $-0,025$ & $0,015 *$ & 0,202 & $0,000 * *$ & 0,004 & 0,314 & $-0,182$ & $0,000 * * *$ \\
\hline \multicolumn{9}{|l|}{ Bargain Power: } \\
\hline Pendid ikan ayah dan ibu setara & 0,015 & $0,000 * * *$ & $-0,022$ & $0,000 * *$ & 0,001 & 0,598 & 0,006 & 0,134 \\
\hline Pendid'kan lebih tinggi ibu & 0,024 & $0,000 * * *$ & $-0,049$ & $0,000 * *$ & 0,006 & $0,040 * *$ & 0,019 & $0,001 * * *$ \\
\hline Jenis Kelamin KRT & $-0,025$ & $0,000 * * *$ & 0,048 & $0,000 * *$ & $-0,012$ & $0, \infty 1 * *$ & $-0,011$ & $0,067^{*}$ \\
\hline \multicolumn{9}{|l|}{ Pendidikan Ibu: } \\
\hline wlus Sekolah Dasar & $-0,023$ & $0,000 * * *$ & 0,048 & $0,000 * *$ & $-0,002$ & 0,220 & $-0,023$ & $0,000 * * *$ \\
\hline Sekol ah Menengah & $-0,044$ & $0,000 * * *$ & 0,090 & $0,000 * *$ & $-0,006$ & $0,021 * *$ & $-0,041$ & $0,000 * * *$ \\
\hline Sekolah Tinggi & $-0,032$ & $0,000 * * *$ & 0,099 & $0,000 * *$ & $-0,011$ & $0,000 * * *$ & $-0,055$ & $0,000 * * *$ \\
\hline Statuswilayah tempat tingga & 0,005 & $0,024 * *$ & $-0,023$ & $0,000 * *$ & 0,004 & $0,011 * *$ & 0,013 & $0,000 * * *$ \\
\hline Jenis Kelamin Anak & 0,016 & $0,000 * * *$ & $-0,006$ & 0,106 & 0,003 & $0,018 * *$ & $-0,013$ & $0,000 * * *$ \\
\hline \multicolumn{9}{|l|}{ Umur Anak: } \\
\hline 11 & 0,000 & 0,502 & $-0,005$ & 0,167 & 0,001 & 0,605 & 0,004 & 0,244 \\
\hline 12 & 0,000 & 0,510 & $-0,021$ & $0,000 * * *$ & 0,005 & $0, \infty 07 * * *$ & 0,015 & $0,000 * * *$ \\
\hline 13 & 0,007 & $0,000 * * *$ & $-0,053$ & $0,000 * *$ & 0,006 & $0,007 * * *$ & 0,041 & $0,000 * * *$ \\
\hline 14 & 0,016 & $0,000 * * *$ & $-0,0 \mathrm{BS}$ & $0,000 * *$ & 0,010 & $0,000 * * *$ & 0,060 & $0,000 * * *$ \\
\hline 15 & 0,043 & $0,000 * * *$ & $-0,148$ & $0,000 * *$ & 0,016 & $0,000 * * *$ & 0,090 & $0,000 * * *$ \\
\hline 16 & $0,0 \mathrm{BO}$ & $0,000 * * *$ & $-0,211$ & $0,000^{* * *}$ & 0,019 & $0,000 * * *$ & 0,112 & $0,000 * * *$ \\
\hline 17 & 0,145 & $0,000 * * *$ & $-0,329$ & $0,000 * *$ & 0,016 & $0,000 * * *$ & 0,168 & $0,000 * * *$ \\
\hline \multicolumn{9}{|l|}{ Pendidikan Anak: } \\
\hline Lulus Sekolah Dasar & $-0,012$ & $0,017^{* *}$ & 0,045 & $0,000 * *$ & 0,004 & $0,042 * *$ & $-0,037$ & $0,000 * * *$ \\
\hline Sekol ah Menengah & 0,026 & $0,006 * * *$ & $-0,163$ & $0,000 * *$ & 0,001 & 0,860 & 0,137 & $0,000 * * *$ \\
\hline \multicolumn{9}{|l|}{ Bahan Bakar Utama Memasak } \\
\hline Kayu Bakar & 0,018 & $0,000 * *$ & $-0,039$ & $0,000 * *$ & 0,003 & $0,084^{*}$ & 0,019 & $0,000 * * *$ \\
\hline Lainnya & $-0,004$ & 0,484 & $-0,003$ & 0,790 & 0,002 & 0,698 & 0,005 & 0,589 \\
\hline \multicolumn{9}{|l|}{ Lapangan Kerja KRT: } \\
\hline Industri & $-0,005$ & 0,222 & 0,011 & 0,107 & 0,005 & 0,143 & $-0,011$ & $0,055^{*}$ \\
\hline Jasa & $-0,015$ & $0,000 * * *$ & 0,031 & $0,000 * *$ & 0,001 & 0,706 & $-0,017$ & $0,000 * * *$ \\
\hline Perdagangan dan Transportas & $-0,014$ & $0,000 * * *$ & 0,014 & $0,009 * *$ & 0,003 & 0,139 & $-0,003$ & 0,466 \\
\hline Sektor Lainnya & $-0,006$ & $0,082^{*}$ & 0,002 & 0,751 & 0,006 & $0,021 * *$ & $-0,002$ & 0,684 \\
\hline \multicolumn{9}{|l|}{ Status dalam Pekerjaan KRT: } \\
\hline Buruh/ karyawan & $-0,001$ & 0,499 & 0,003 & 0,427 & $-0,007$ & $0,000 * * *$ & 0,005 & $0,090^{*}$ \\
\hline Pekerja Keluarga/ tidak dibayar & 0,003 & 0,730 & 0,009 & 0,540 & 0,004 & 0,548 & $-0,015$ & 0,166 \\
\hline
\end{tabular}

Sumber data: Hasil olah data SUPAS2015 Jawa Timur

Catatan: $*=$ Sign.pada level 10\%, $* *=$ Sign.pada level 5\%***= Sign.pada level 1\% 
anak yang berasal dari tlatah pandalungan paling kecil peluangnya untuk bersekolah $(\mathrm{ME}=-0,022)$ namun paling besar peluangnya untuk tidak sekolah dan tidak bekerja $(\mathrm{ME}=0,031)$ dibandingkan anak dari tlatah lainnya. Anak yang berasal dari tlatah Madura Pulau paling berpeluang untuk sekolah sambil bekerja dibandingkan anak dari tlatah lainnya.

Hasil temuan ini semakin mendukung peranan budaya dalam keterlibatan anak dalam dunia kerja serta partisipasi anak sekolah. Seperti pada penelitian McEwan \& Trowbridge (2007) dan Vasquez \& Bohara (2010) yang menemukan fakta bahwa etnis penduduk asli (indigenous) lebih memungkinkan menjadi pekerja anak dan kurang memungkinkan untuk sekolah dari pada penduduk nonindigenous.

\section{b. Pengaruh Kemampuan Berbahasa Indonesia}

Anak yang hanya kemampuan berbahasa Indoensia dengan baik akan mempunyai peluang $20,2 \%$ lebih besar untuk bersekolah $(\mathrm{ME}=0,202)$ daripada yang tidak punya kemampuan berbahasa Indonesia yang baik. Sebaliknya anak yang punya kemampuan berbahasa Indonesia dengan baik mempunyai peluang lebih kecil untuk bekerja atau tidak sekolah dan tidak bekerja.

Hasil penelitian pada variabel kemampuan berbahasa Indonesia di atas mendukung hasil penelitian Patrinos \& Psacharopoulos (1995) yang menyatakan bahwa kemampuan menguasai bahasa nasional sebagai sarana komunikasi berpengruh signifikan terhadap prestasi anak di sekolah, tingkat putus sekolah dan pendapatan anak jika bekerja.

\section{c. Pengaruh Bargaining Power Orang Tua}

Pengaruh bargaining power orang tua diproxikan dari tingkat relatif pendidikan KRT dan pasangannya. Kategori pendidikan ayah lebih tinggi dari ibu dijadikan acuan terhadap kategori bargaining power yang lain. Pada penelitian ini, anak yang hanya memiliki salah satu orangtua tidak diikutsertakan dalam analisis dengan tujuan untuk lebih menguatkan hasil penelitian tentang bargaining power

Dari hasil marginal effect, diketahui bahwa saat pendidikan ibu setara dengan ayah atau bahkan lebih tinggi dari ayah, peluang anak bekerja atau bekerja sambil bersekolah menjadi lebih besar. Sebaliknya peluang anak bersekolah justru menurun. Hal ini mengindikasikan tingkat putus sekolah anak justru meningkat saat bargaining power ibu lebih tinggi dari ayah. Menariknya, peluang anak tidak sekolah dan tidak bekerja lebih besar dari peluang anak sekolah sambil bekerja.

Hasil penelitian ini mendukung temuan Ahmed \& Ray (2011) serta Basu \& Ray ( 2002), dimana pendidikan relatif ibu yang lebih tinggi daripada ayah mempunyai dampak marjinal lebih kuat pada trade off sekolah dan kerja anak.

\section{d. Pengaruh Jenis Kelamin KRT}

Dari hasil marginal effect, diketahui bahwa anak dengan KRT peREMpuan lebih berpeluang untuk bekerja dibandingkan anak dengan KRT laki-laki. Sebaliknya anak dengan KRT laki-laki lebih berpeluang untuk bersekolah dibandingkan anak dengan KRT peREMpuan. Hal ini mengindikasikan bahwa KRT peREMpuan lebih cenderung melibatkan anak-anak mereka untuk bekerja saat ada tawaran kerja bagi anak-anak mereka. Asumsinya, KRT peREMpuan merasa perlu dibantu perekonomian rumah tangganya (dengan posisi masih atau tidak memiliki suami) dengan cara melibatkan anak-anak mereka bekerja.

Hal penelitian ini berbeda dengan penelitian Pratomo (2017) namun serupa dengan penelitian Pitriyan (2006) yang menyatakan bahwa anak dengan KRT peREMpuan lebih memungkinkan bekerja dibanding bersekolah.

\section{e. Pengaruh Pendidikan Ibu}

Dari hasil marginal effect, diketahui bahwa semakin tinggi tingkat tingkat pendidikan ibu, semakin besar peluang anak bersekolah. Selain itu semakin kecil peluang anak sekolah sambil bekerja serta semakin kecil peluang anak tidak sekolah dan tidak kerja. Namun pengaruh pada keterlibatan anak bekerja secara murni menjadi bias karena awalnya tingkat partisipasi anak bekerja turun seiring meningkatnya pendidikan ibu hingga lulus sekolah menengah. Tetapi ketika ibu sudah mencapai pendidikan tinggi, partisipasi anak bekerja kembali naik.

Hasil penelitian ini mendukung penemuan dari Edmonds (2007), Metrotra el al. (2010), dan setyari (2013). Dimana dalam penelitian mereka menyebutkan bahwa semakin tinggi tingkat pendidikan ibu semakin tinggi kemungkinan anak bersekolah.

\section{f. Pengaruh Status Wilayah Tempat Tinggal}

Dari hasil marginal effect, diketahui bahwa anak yang tinggal di wilayah pedesaan berpeluang $0,5 \%$ lebih besar untuk bekerja; berpeluang $0,4 \%$ 
lebih besar untuk sekolah sambil bekerja serta berpeluang 1,3\% lebih besar untuk tidak bekerja dan tidak sekolah dibandingkan anak yang tinggal di wilayah perkotaan. Selain itu, anak yang tinggal di wilayah pedesaan berpeluang 2,3\% lebih kecil untuk bersekolah dibandingkan anak yang tinggal di wilayah perkotaan.

Hasil penelitian di atas mendukung beberapa penelitian terdahulu oleh Edmonds (2007), Tang (2016), dan Metrotra el al. (2010). Dikatakan bahwa anak yang tinggal di wilayah pedesaan lebih rentan bekerja dibandingkan anak yang tinggal di wilayah perkotan. Sebaliknya anak perkotaan lebih berpeluang untuk sekolah dibandingkan anak yang tinggal di wilayah pedesaan.

\section{g. Pengaruh Jenis Kelamin Anak}

Dari hasil marginal effect, diketahui bahwa anak laki-laki lebih berpeluang untuk bekerja atau sekolah sambil kerja dibandingkan anak peREMpuan. Namun peluangnya anak lakilaki untuk bekerja saja lebih besar dibandingkan peluangnya untuk sekolah sambil kerja atau tidak sekolah dan tidak bekerja. Sedangkan anak peREMpuan lebih berpeluang tidak sekolah dan tidak bekerja dibandingkan anak laki-laki. Untuk kategori anak sekolah saja, variabel jenis kelamin anak tidak berpengaruh signifikan.

Hasil penelitian ini berbeda dengan temuan Edmonds (2007) namun selaras dengan penelitian Contreas et al. (2007) dan Pratomo (2017) yang menyatakan bahwa abak laki-laki lebih berpeluang terjun ke dalam dunia kerja.

\section{h. Pengaruh Umur Anak}

Dari hasil marginal effect, diketahui bahwa dengan bertambahnya umur anak, peluang anak bekerja, sekolah sambil kerja serta tidak sekolah dan tidak bekerja semakin besar. Sebaliknya, peluang anak untuk sekolah saja semakin kecil dengan bertambahnya umur anak. Hal ini menandakan bahwa kecenderungan anak bekerja dan putus sekolah semakin besar dengan bertambahnya umur anak. Asumsi yang mendasari bahwa dengan bertambahnya usia anak, rasa tanggung jawab untuk membantu ekonomi rumah tangga semakin meningkat. Sehingga mendorong anak semakin terlibat dalam dunia kerja, walaupun harus dengan cara putus sekolah sekalipun.

Hasil penelitian ini mendukung temuan pada penelitian dari Pratomo (2017) yang menunjukkan bahwa dengan bertambahnya umur anak, peluang anak bekerja semakin besar. Namun sebaliknya, peluang anak untuk sekolah semakin kecil.

\section{i. Pengaruh Pendidikan Anak}

Dari hasil marginal effect, diketahui bahwa diindikasikan adanya bias pengaruh pendidikan anak. Pada awalnya peluang anak bekerja turun dan peluang anak sekolah naik saat anak lulus sekolah dasar. Namun peluang anak bekerja kembali naik dan anak sekolah justru turun saat anak lulus sekolah menengah.

Hal itu terlihat dari nilai marginal effects yang awalnya negatif saat anak lulus sekolah dasar menjadi positif saat anak lulus sekolah menengah pada kategori anak bekerja.

Bias pengaruh pendidikan anak didasari atas asumsi bahwa adanya program wajib belajar 9 tahun dan program sekolah gratis dari pemerintah yang membantu anak untuk terus sekolah setidaknya sampai lulus sekolah dasar (SD dan SMP sederajat). Sedangkan setelah lulus sekolah menengah (SMA sederajat), kecenderungan anak untuk bekerja sangat tinggi. Asumsinya anak setelah lulus SMA merasa wajib meringankan beban ekonomi rumah tangga. Sehingga pilihan untuk bekerja daripada sekolah adalah hal yang lumrah.

Namun yang menarik yaitu kecenderungan anak untuk putus sekolah dan tidak bekerja paling besar di antara kategori aktivitas anak yang lain untuk variabel anak lulus pendidikan menengah. Ini mengisyaratkan bahwa belum tentu selepas lulus sekolah menengah, anak-anak langsung bekerja. Hal itu mungkin karena belum tersedianya lapangan kerja atau enggan untuk bekerja pada suatu lapangan kerja yang tidak sesuai dengan kualifikasi pendidikannya.

\section{j. Pengaruh Bahan Bakar Utama Memasak}

Jenis bahan bakar LPG menjadi variabel acuan terhadap kategori bahan bakar lainnya.

Dari hasil marginal effect, diketahui bahwa anak yang rumah tangganya menggunakan bahan bakar memasak berjenis kayu bakar lebih berpeluang untuk bekerja, lebih berpeluang untuk sekolah sambil bekerja, lebih berpeluang untuk tidak sekolah dan tidak bekerja, dan kurang berpeluang untuk bersekolah dibandingkan anak yang rumah tangganya menggunakan bahan bakar gas LPG.

\section{k. Pengaruh Jenis Lapangan Kerja KRT}

Sektor lapangan usaha yang dijadikan acuan terhadap sektor usaha yang lain yaitu sektor 
pertanian.

Dari hasil marginal effect, diketahui bahwa anak dengan KRT bekerja di sektor pertanian paling berpeluang untuk bekerja dibandingkan anak dengan KRT bekerja disektor lainnya. Anak dengan KRT bekerja di sektor perdagangan dan transportasi paling berpeluang bersekolah dibandingkan sektor lainnya. Serta anak dengan KRT bekerja di sektor lainnya paling berpeluang sekolah sambil bekerja dibandingkan sektor lainnya. Sedangkan anak dengan KRT bekerja di sektor industri dan di sektor jasa paling kecil peluangnya untuk tidak sekolah dan tidak bekerja.

Hasil penelitian ini mendukung temuan pada penelitian dari Edmonds (2007) dan Tang et al. (2016) yang menunjukkan bahwa jenis lapangan pekerjaan orang tua (dalam hal ini sektor pertanian) berpengaruh signifikan dalam keterlibatan anak bekerja dan sekolah.

\section{l. Pengaruh Status dalam Pekerjaan Utama KRT}

Status pekerjaan utama KRT yang dijadikan acuan adalah KRT yang bekerja sebagai pengusaha. Hal ini karena jumlah anak yang bekerja adalah anak yang ayahnya bekerja sebagai pengusaha.

Dari hasil marginal effect, diketahui bahwa anak dengan KRT bekerja sebagai buruh/karyawan kurang berpeluang untuk sekolah sambil bekerja dibandingkan anak dengan KRT bekerja sebagai pengusaha. Namun yang mengkhawatirkan adalah peluang putus sekolah namun menganggur lebih besar pada anak dengan KRT bekerja sebagai buruh/ karyawan.

Hasil penelitian ini berbeda dengan temuan Edmonds (2007) yang mengemukakan adanya perbedaan keterlibatan anak bekerja pada rumah tangga yang mempunyai usaha rumah tangga dan tidak mempunyai. Pada penelitian ini, ditemukan tidak ada perbedaan antara anak dengan KRT bekerja sebagai pengusaha dengan anak yang KRT nya bekerja sebagai buruh/ karyawan/ pekerja keluarga.

\section{KESIMPULAN}

Dari hasil analisa di atas, dapat disimpulkan bahwa budaya dan bargaining power memberikan pengaruh yang signifikan terhadap partisipasi sekolah dan kerja anak. Anak yang berasal dari tlatah Arek paling berpeluang bekerja dibandingkan anak dari tlatah lainya. Sedangkan anak yang berasal dari tlatah pandalungan paling kecil peluangnya untuk bersekolah namun paling besar peluangnya untuk tidak sekolah dan tidak bekerja dibandingkan anak dari tlatah lainnya. Anak yang berasal dari tlatah Madura Pulau paling berpeluang untuk sekolah sambil bekerja dibandingkan anak dari tlatah lainnya.

Sedangkan saat pendidikan ibu setara dengan ayah atau bahkan lebih tinggi dari ayah, peluang anak bekerja atau bekerja sambil bersekolah menjadi lebih besar. Sebaliknya peluang anak bersekolah justru menurun. Hal ini mengindikasikan tingkat putus sekolah anak justru meningkat saat bargaining power ibu lebih tinggi dari ayah.

Implikasi dari penelitian ini adalah memberlakukan dengan tegas UU Nomor 23 tahun 2002 tentang Perlindungan Anak yang berupaya menghapus kegiatan eksploitasi anak. Selain itu perlu dibentuk komite aksi daerah yang bertugas menghapus bentuk pekerjan terburuk bagi anak dan mengedukasian tentang dampak negatif anak bekerja. Utamanya pada wilayah-wilayah yang secara kultur budaya memiliki pengaruh terhadap semakin tingginya partisipasi kerja anak dan rendahnya sekolah anak.

\section{REFERENSI}

Ahmed, Salma, dan Ranjan Ray. 2011. "Parent's Bargaining powers, Child Labour and Education." (December).

Akabayashi, H \& G. Psacharopoulos. 1999. The Trade-Off Between Child Labour And Human Capital Formation: A Tanzanian Case Study. Journal of Development Studies 35: 120-140

Ayu, Cintia Putri \& Bachtiar, Nasri. 2017. Analisis Faktor-Faktor Mempengaruhi Pekerja Anak Di Sumatera Barat. Fakultas Ekonomi Universitas Andalas

Badan Pusat Statistik. 2009. Pekerja Anak di Indonesia 2009. Jakarta

Badan Pusat Statistik. 2015. Petunjuk Teknis Pencacahan SUPAS 2015. Jakarta

Badan Pusat Statistik. 2017. Analisis Kemiskinan Anak dan Deprivasi Hak-hak Dasar Anak di Indonesia. Jakarta 
Barham, V et al. 1995. Education and the poverty trap. European Economic Review 39: 1257-1275.

Basu, K \& Ranjan Ray. 2002. The Collective Model of the Household and an Unexpected Implication for Child Labor. The World Bank Office of the Senior Vice President H Development Economics: Policy Research Working Paper 2813

Contreas, Dante et al. 2007. Child Labor and Schooling in Bolivia: Who's Falling Behind? The Roles of Domestic Work, Gender and Ethnicity. Departemento De Economia, Universidad De Chile

Donni, O. 2003. Collective household labor supply: Non-participation and income taxation. The Journal of Public Economics, 87(5/6), 1179-98.

Edmonds, E. V., \& Pavcnik, N. 2005. Child Labor in the Global Economy. Journal of Economic Perspectives, 19(1).

Edmonds, E. V. 2007. Child labor. NBER Working Paper No. 12926. National Bureau Of Economic Research

Guarcello, L et al. 2004. Child labour and access to basic services Evidence from five countries. UCW - Understanding Children's Work Project

Gujarati, Damodar N. 2010. Dasar-Dasar Ekonometrika Buku 1. Edisi 5. ed. Dedy A. Halim. Jakarta: Penerbit Salemba Empat.

Hopkins et al. 1994. Women's Income and Household Expenditure Patterns: Gender or Flow? Evidence from Niger. American Journal of Agricultural Economics, Vol. 76 (7), pp. 1219-1225.

Himmelwei et al. 2013. Sharing of Resources within the Family and the Economics of Household Decision-making. The Open University. United Kingdom.

Kurosaki et al. 2006. Child Labor and School
Enrollment in Rural India: Whose Education Matters?. Forthcoming in The Development Economics, Vol 44 (6).

McEwan, Patrick J.\& Marisol Trowbridge. 2007 The Achievement of Indigenous Students in Guatemalan Primary Schools. International Journal of Educational Development 27 (1): 61-76.

Mehrotra, Santosh \& Mario Biggeri. 2010. Children in home worker households in Pakistan and Indonesia. International Journal of Manpower, Vol. 31 Issue: 2, pp.208-231

Pratomo, Devanto S. 2017. Does Poverty Affects Child Labour and School Attendance?: Evidence from Indonesia. Proceeding The 3 International Indonesian Forum for Asian Studies Challenges of globalisation.

Ray, Ranjan. 2000. Child Labors, Child Schooling, and Their Interaction with Adult Labor: Empirical Evidence for Peru and Pakistan. The World Bank Economic Review, 14(3):347-67.

Setyari, Ni Putu Wiwin. 2013. Distribusi Alokasi Sumber Daya Dalam Rumah Tangga di Indonesia : Anak Sekolah atau Bekerja?. Jurnal Piramida Vol. IX No. 2 : 59 - 71

Sutarto, Ayu. 2004. Pendekatan Kebudayaan dalam Pembangunan Provinsi Jawa Timur. 1 ed. Jember: Kompyawisda

Tang, Can et al. 2016. Child labor in China. Journal of China Economic Review. Elsevier B.V.

Thomas, Duncan et al. 1999. Distribution of Power Within the Household and Child Health. Unpublised manuscript, download at www.rand.org

Vasquez, William F \& Alok K. Bohara. 2010. Household Shocks, Child Labor, And Child Schooling. Latin American Research Review, Vol. 45, No. 2. (C) 2010 by the Latin 
Pengaruh Budaya \& Bargaining Power Terhadap... [Faishol Amir, Khusnul Ashar, Devanto Shasta Pratomo]

American Studies Association

Vermeulen, F. 2006. A Collective Model for

Female labor supply with nonparticipation

and taxation. Journal of Population

Economics, 19(1), 99-118 